or in association with meningeal leukaemia. In our case the patient was off treatment and there were no other leukaemic manifestations.

Although radiotherapy to the eye proved effective, a case such as this must be regarded as having relapsed and therefore requiring further courses of antileukaemic drugs.

We thank Professor F. Fossati who performed ocular radiotherapy.

\section{References}

Allen, R. A., and Straatsma, B. R. (1961). Ocular involvement in leukemia and allied disorders. Archives of Ophthalmology, 66, 490-508.

Evans, A. E. (1964). Central nervous system involvement in children with acute leukemia; a study of 912 patients. Cancer, 17, 256-258.

Kearney, W. F. (1973). Leukemic hypopyon: a report of two cases. American Journal of Ophthalmology, 59, 495-497.

Mark, L. E., Rouhani, J., and Sawitsky, A. (1974). Leukemic iris infiltration in a case of meningeal leukemia. Annals of Ophthalmology, 6, 669-674.

Murray, K. H., Paolino, F., Goldman, J. M., Galton, D. A. G., and Grindle, C. F. J. (1977). Ocular involvement in leukaemia. Report of three cases. Lancet, 1, 829-831.

Ridgway, E. W., Jaffe, N., and Walton, D. S. (1976). Leukemic ophthalmology in children. Cancer, 38, 1744-1749.

Sansone, G., and Mariotti, L. (1953). Le manifestazioni oculari delle leucemie acute dell'infanzia con particolare riguardo alla retinopatia leucemica. Annali di of ttalmologia e clinica oculistica, 3, 169-194.

Correspondence to Professor G. Masera, Department of Paediatrics, University of Milan, Clinica De Marchi, Via Commenda, 9-20122 Milan, Italy.

\title{
Reye's syndrome associated with respiratory syncytial virus infection
}

\author{
N. GRIFFIN, J. W. KEELING, AND A. H. TOMLINSON \\ Department of Paediatrics and Pathology, John Radcliffe Hospital, and the Virology Laboratory, \\ Churchill Hospital, Headington, Oxford
}

SUMMARY An upper respiratory tract infection in a 22-month-old boy was followed by rapid loss of consciousness, hypoglycaemia, uraemia, and death. Necropsy examination showed fatty change of liver and kidneys, severe cerebral oedema, bronchiolitis, and endocardial fibroelastosis affecting the left ventricle. Immunofluorescence staining showed infection with respiratory syncytial virus (RSV). The clinical and pathological findings were those of Reye's syndrome, not previously reported accompanying RSV infection.

Reye et al. (1963) described a syndrome of acute encephalopathy and fatty degeneration of the viscera. The association with an acute respiratory virus infection has often been noted, but respiratory syncytial virus (RSV) has not, to our knowledge, been implicated. We report a fatal case of Reye's syndrome associated with a RSV infection.

\section{Case report}

A boy of 22 months developed a mild upper respiratory tract infection with nonproductive cough and coryza which was treated with a proprietory linctus. On the 3rd morning he did not wake at the usual time but was seen by his mother at 8.30 a.m. to be sleeping peacefully with normal respirations. At
9.30 a.m. she found him blue, limp, and dyspnoeic.

On admission one hour later he was found to have peripheral vasoconstriction, central cyanosis, and to be in shock. Systolic blood pressure was $60 \mathrm{mmHg}$, pulse $88 / \mathrm{min}$, and respiratory rate $48 / \mathrm{min}$. He responded only to painful stimuli, his respirations were shallow, noisy, and irregular. There was diminished air entry, particularly on the left, coarse moist sounds and expiratory rhonchi were present bilaterally. The liver was not palpable. Retinal examination and reflexes were normal. His condition deteriorated rapidly; coma deepened, muscle tone increased, plantar responses became extensor. Treatment with dextrose/saline, hydrocortisone, antibiotics, and oxygen was ineffective; he died 3 hours after admission.

Investigations. Total WBC count $18800 / \mathrm{mm}^{3}(18 \cdot 8$ $\left.\times 10^{9} / \mathrm{l}\right)$ with mild neutrophilia, blood urea 69 $\mathrm{mg} / 100 \mathrm{ml}(11.5 \mathrm{mmol} / \mathrm{l})$, bicarbonate $17 \mathrm{mEq} / \mathrm{l}$, blood sugar $10 \mathrm{mg} / 100 \mathrm{ml}(0.56 \mathrm{mmol} / \mathrm{l}), \mathrm{CSF}$ and blood cultures were sterile. Nose and throat swabs yielded normal flora.

Necropsy. A well nourished baby boy $89 \mathrm{~cm}$ crown/ heel length, weighing $11.6 \mathrm{~kg}$. The brain was swollen $(1170 \mathrm{~g})$; slicing after fixation showed obliteration of sulci. The larynx was injected, trachea and main bronchi contained purulent mucus, 
and the epithelium was swollen and purplish. The lungs were bulky with petechial haemorrhages and foci of collapse throughout (right $110 \mathrm{~g}$, left $102 \mathrm{~g}$ ). The heart was slightly enlarged $(64 \mathrm{~g})$ but anatomically normal, left ventricular hypertrophy and dilatation with pearly white thickening of the left ventricular endocardium was present, valves healthy. The liver was enlarged ( $554 \mathrm{~g}$ ), pale yellow, and greasy to touch. Other organs were healthy.

Histological examination of the liver showed gross fatty change throughout the lobules and fat droplets present in renal tubular epithelium. In the lung, bronchi and bronchioles were plugged with mononuclear cells, lining epithelium was cuboidal, and the wall infiltrated by inflammatory cells with patchy extension into alveoli. A subendocardial layer of fibroelastic tissue was present in the left ventricle. There was cerebral oedema but no inflammatory cell infiltration of brain or meninges.

Virological investigation. Secretions aspirated from the nasopharynx, on admission, were inoculated on to tissue cultures on monkey kidney, human amnion, and Hep 2 cells. No virus was isolated. Cells from the aspirate stained by the immunofluorescence technique of McQuillin and Gardner (1968) showed specific fluorescence for RSV.

Brain tissue collected at necropsy was inoculated on to human amnion and monkey kidney cells, but no virus was isolated. Post-mortem lung also failed to yield virus when cultured on the same cells as the aspirate. A piece of lung, $10 \times 10 \times 5 \mathrm{~mm}$, was snap frozen and sections, $6 \mu \mathrm{m}$ thick, were cut in a cryostat, air-dried, and fixed with acetone. Sections were stained for RSV using bovine antiviral serum* $(1: 80)$ and fluorescein conjugated rabbit antibovine globulin* $(1: 40)$. Control sections were treated with bovine serum free of antibody. In each test section there were 2 or 3 small bronchi with fluorescent cells in the epithelium (Figure); no such fluorescence appeared in the control sections.

Complement-fixation tests on serum collected at necropsy gave the following titres: parainfluenza virus 1:16; mumps 1:8; RSV influenza A, Mycoplasma pneumoniae, psittacosis, Coxiella burnetii, herpes simplex virus, and cytomegalovirus all 1:8.

\section{Discussion}

The aetiology of Reye's syndrome is still uncertain. An association between it and various drugs and chemicals has been reported (Glasgow and Ferris, 1968; Shield et al., 1977) but there does not seem to be an association with a particular molecular

*Wellcome Reagents Ltd.

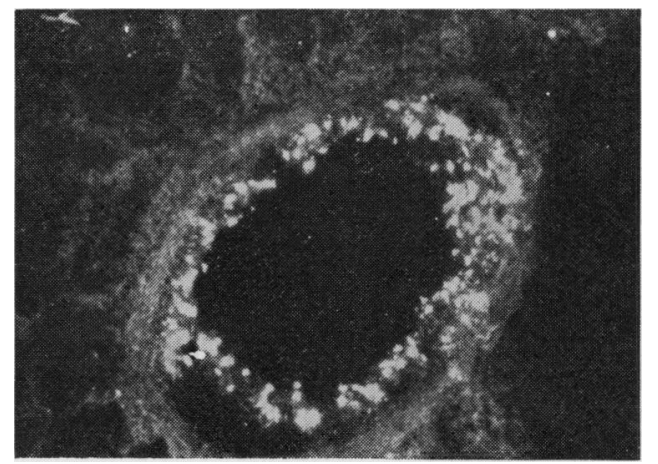

Figure Immunofluorescence staining of RSV antigen in the epithelial cells of a small bronchus. $(\times 180)$.

configuration. The frequency of a mild prodromal illness may partly explain the association with salicylate ingestion, although in one report several children were taking high doses of salicylate (Linneman et al., 1975). Aflatoxin ingestion has been incriminated in some countries, but its precise role is unknown (Hogan et al., 1978). The most commonly reported association is that of Reye's syndrome and virus infection. Influenza B virus is the most often implicated although in some cases infection with influenza $A$, parainfluenza, and adenovirus or varicellazoster virus has been shown by isolation or serology (Linneman et al., 1975). In this case, RSV was demonstrated by immunofluorescence but was not isolated in tissue culture, which is not unexpected as this virus is difficult to grow from necropsy specimens. The histological appearances of the lungs in this child are typical of bronchiolitis. The presence of endocardial fibroelastosis may have contributed to this boy's death; some children with this condition die suddenly and unexpectedly, but many more are precipitated into heart failure by an apparently trivial infection. Heart failure alone would not be expected to produce severe panlobular fatty change in the liver but rather a centrilobular distribution of fatty change, possibly associated with necrosis. Similarly, renal tubular fatty change could not be attributed to heart failure.

Reye's syndrome has not been reported previously as a complication of RSV infection and it is perhaps of particular interest that a bronchiolitis rather than a pneumonia is present in this case, in view of the suggestion that bronchiolitis is an allergic response to a virus antigen (Gardner et al., 1970). The association of Reye's syndrome with a variety of virus infections and the absence of viral invasion of brain or liver suggests the participation of an additional factor, metabolic or toxic, in the pathogenesis of this condition. 


\section{References}

Gardner, P. S., McQuillin J., and Court, S. D. M. (1970). Speculation on pathogenesis in death from respiratory syncytial virus infection. British Medical Journal, 1, 317330.

Glasgow, J. F. T., and Ferris, J. A. J. (1968). Encephalopathy and visceral fatty infiltration of probable toxic aetiology. Lancet, 1, 451-453.

Hogan, G. R., Ryan, N. J., and Hayes, A. W. (1978). Letter: Aflatoxin B1 and Reye's syndrome. Lancet, 1, 561.

Linneman, C. C., Jr, Shea, L., Partin, J. C., Schubert, W. K., and Schiff, G. M. (1975). Reye's syndrome: epidemiologic and viral studies, 1963-1974. American Journal of Epidemio$\log y, 101,517-526$.
McQuillin, J., and Gardner, P. S. (1968). Rapid diagnosis of respiratory syncytial virus infection by immunofluorescent antibody technique. British Medical Journal, 1, 602-605.

Reye, R. D. K., Morgan, G., and Baral, J. (1963). Encephalopathy and fatty degeneration of the viscera: a disease entity in childhood. Lancet, 2, 749-752.

Shield, L. K., Coleman, T. L., and Markesbery, W. R. (1977). Methyl bromide intoxication: neurologic features, including simulation of Reye's syndrome. Neurology (Minneapolis), 27, 959-962.

Correspondence to Dr J. W. Keeling, Department of Pathology, John Radcliffe Hospital, Headington, Oxford OX3 9DU.

\title{
Chloramphenicol and phenobarbitone-a drug interaction
}

\author{
R. A. BLOXHAM, G. M. DURBIN, T. JOHNSON, AND M. H. WINTERBORN \\ Department of Paediatrics, East Birmingham District General Hospital, Birmingham
}

SUMMARY Two infants with meningitis who were treated with phenobarbitone and high-dose chloramphenicol showed progressive falls in the peak blood levels of chloramphenicol. A standard chloramphenicol dose of $50 \mathrm{mg} / \mathrm{kg}$ daily would have produced subtherapeutic blood levels after only a few days. The importance of measuring serial blood chloramphenicol concentrations is stressed.

Infants and young children with bacterial meningitis are often treated with phenobarbitone to prevent convulsions. Chloramphenicol is the antibiotic of choice for the treatment of Haemophilus influenzae meningitis. A possible interaction between these two drugs is recognised (Bella et al., 1968) but has not been specifically reported in man. We therefore report two infants with $H$. influenzae meningitis treated with phenobarbitone and chloramphenicol, in whom peak blood levels of chloramphenicol decreased with time in spite of maximum recommended dosage. The first case alerted us to the problem, the second prompted a more detailed study.

\section{Case reports}

Case 1. This 7-month-old girl presented with a 4-day history of upper respiratory infection, followed on the day of admission by fever, lethargy, irritability, and refusal to feed. Cultures of blood and CSF gave a pure growth of $H$. influenzae, sensitive to chloramphenicol. She was treated with IV chloramphenicol succinate $(100 \mathrm{mg} / \mathrm{kg}$ per $24 \mathrm{~h})$ plus phenobarbitone $(10 \mathrm{mg} / \mathrm{kg}$ per $24 \mathrm{~h}$ ). Blood chloramphenicol concentration was measured by bioassay based on the method described by Louie et al. (1976). Peak blood chloramphenicol levels were $31 \mathrm{mg} / 1$ on days 2 and 3 but they fell to less than $5 \mathrm{mg} / \mathrm{l}$ on day 5 . On day 6 oral treatment with pure chloramphenicol in the same dose was substituted. On day 8 the peak blood level was still $<5 \mathrm{mg} / \mathrm{l}$ and the dose of chloramphenicol was therefore doubled $(200 \mathrm{mg} / \mathrm{kg}$ per $24 \mathrm{~h})$. Subsequently, peak blood levels of between 7 and $11 \mathrm{mg} / \mathrm{l}$ were maintained until day 23 , when treatment was stopped. Her subsequent progress was unremarkable and she remains in good health 12 months later.

Case 2. This 3-month-old boy presented with a one-day history of vomiting, fever, lethargy, and irritability culminating in a brief convulsion. Cultures of blood and CSF gave a pure growth of $H$. influenzae, sensitive to chloramphenicol. He was treated with IV chloramphenicol succinate (100 $\mathrm{mg} / \mathrm{kg}$ per $24 \mathrm{~h}$ ) for 8 days, before being changed to oral pure chloramphenicol in the same dosage. He was treated throughout his illness with phenobarbitone $(10 \mathrm{mg} / \mathrm{kg}$ per $24 \mathrm{~h})$. Chloramphenicol was given for a total of 19 days and he made a full recovery. Although chloramphenicol blood levels were initially satisfactory, they fell rapidly during the first few days of IV treatment (Figure). The biological half-life of chloramphenicol fell from $7 \mathrm{~h}$ $18 \mathrm{~min}$ on the 3 rd day to $4 \mathrm{~h} 6 \mathrm{~min}$ on the 5 th.

\section{Discussion}

$90 \%$ of chloramphenicol is inactivated in the liver either by conjugation with glucuronic acid or by reduction to aryl amines before being excreted in the urine. The remaining $10 \%$ is excreted unaltered in the urine. In these two infants there was a rapid 